\title{
UNIONS AND THE ADOPTION OF HIGH PERFORMANCE WORK SYSTEMS: DOES EMPLOYMENT SECURITY PLAY A ROLE?
}

\author{
WENCHUAN LIU, JAMES P. GUTHRIE, \\ PATRICK C. FLOOD, and SARAH MACCURTAIN*
}

\begin{abstract}
Previous research on the association between unionization and the adoption of high performance work systems (HPWSs) has yielded inconsistent results. Using data from a 2004 multi-industry survey of firms operating in the Republic of Ireland, the authors examine the relationship between employee union membership rates and relative use of HPWSs. They also test arguments that employment security may affect the receptiveness of unions to such HR practices. The results indicate that as union representation increased, there was a significant decrease in the use of high performance work systems. Evidence also suggests that providing employment security significantly ameliorated this negative impact.
\end{abstract}

$\mathbf{A}$ substantial body of research since the early 1990s has examined the potential for bundles or systems of human resource policies and practices to influence firm performance. These high performancework systems (HPWSs), which include rigorous staffing procedures, employee participation, job redesign, investments in training, and alterna-

\footnotetext{
*Wenchuan Liu is Associate Professor, Capital University of Economics and Business, Beijing; James P. Guthrie is William and Judy Docking Professor of Business, University of Kansas; Patrick C. Flood is Professor of Organizational Behaviour, Dublin City University; and Sarah MacCurtain is Lecturer in Organisational Behaviour, Kemmy Business School, University of Limerick.

The authors thank the National Centre for Partnership and Performance for research funding and acknowledge the support of Lucy Fallon Bryne, Cathal O'Regan, and Larry O'Connell. They received valuable suggestions from Vince Barker, John Barrett, Deepak Datta, Brendan Halpin, John Kelly, Bill Roche, and Tom Turner and helpful assistance from $\mathrm{Na} \mathrm{Fu}$ and Jing Liu. The first author gratefully acknowledges the funding received from the Irish Research Council for the Humanities and Social Sciences.

Copies of the survey instruments and computer programs used to generate results presented in this paper are available from Patrick C. Flood at the Dublin City University, Ireland: patrick.flood@dcu.ie.
}

tive approaches to compensation (skill-based pay and group incentive compensation), are widely believed to improve organizational performance through their impact on employees' competencies, discretionary authority, and motivation (Bailey 1993; Combs, Liu, Hall, and Ketchen 2006; Delaney and Huselid 1996; Huselid 1995; Pfeffer 1994). Huselid's (1995) study of a sample of publicly traded U.S. firms represented a watershed of sorts. ${ }^{1}$ Its main finding was that greater use of a set of high performance work practices was associated with decreased employee turnover and higher levels of productivity, profitability, and market value. Numerous studies have indicated a positive relationship between high involvement or high performance HR systems and a range of firm outcomes, including productivity (for example, Arthur 1994; Datta, Guthrie, and Wright 2005; Guthrie 2001; Koch and McGrath 1996; MacDuffie 1995 ), financial results in the form of firm

\footnotetext{
${ }^{1}$ The fact that this study has been cited by almost every subsequent empirical strategic human resource management (SHRM) publication supports the notion that it represents a significant and seminal demarcation point.
} 
profitability or market value (Delery and Doty 1996; Huselid 1995), product/service quality (MacDuffie 1995; Youndt, Snell, Dean, and Lepak 1996), and employee turnover (Arthur 1994; Batt 2002; Guthrie 2001).

This stream of research is not without its critics (for example, Bryson, Forth, and Kirby 2005; Gerhart 1999; Godard 2004; Wood and de Menezes 1998) and not all studies provide positive evidence for the value of high performance work systems (Cappelli and Neumark 2001; Guest, Michie, Conway, and Sheehan 2003). Two recent meta-analyses, however, support the conclusion that high performance work systems positively influence firm performance (Combs, Liu, Hall, and Ketchen 2006; Subramony, forthcoming). Combs et al. (2006), for example, aggregated results across 92 studies covering 19,319 organizations and found a corrected effect size of $r_{c}=.20$.

Specific to the setting of this study, Guthrie, Flood, Liu, and MacCurtain (2009) make the empirical case for a positive association between HPWSs and a number of organizational and HR outcomes in firms operating in Ireland. In addition, Horgan and Muhlau (2005) examined the impact of a system of HR practices on firm performance in both Ireland and the Netherlands. One of their research questions centered on a comparison of the relative HRM-firm performance effects in Ireland versus the Netherlands. Based on an analysis of a variety of societal and institutional factors, they argued that their measure of "high performance human resource management" would likely have greater firm performance effects in Ireland than in the Netherlands. Their results strongly supported their arguments.

While many studies have examined employee and organizational consequences associated with the use of HPWSs, with a few notable exceptions (Huselid and Rau 1997; Osterman 1994; Pil and MacDuffie 1996; Roche 1999), less research has systematically examined factors associated with the adoption or use of this approach to HRM. One particularly interesting issue is the extent to which unions affect the use of these HRM innovations, and the nature of this influence. In a unionized company, unions may materially influence members' attitudes and behaviors toward management innovations (Turner 1991). As Godard (2004) pointed out, some have argued that the adoption of HPWSs is antithetical to the interests of unions (Huselid and Rau 1997; Kelly 1996), while others have advanced counter-arguments (Machin and Wood 2005). Paralleling these conflicting arguments, the evidence generated by a small number of extant studies provides equivocal findings.

In this paper, we provide further evidence on the question of whether or not union representation influences the relative use of high performance HR practices. Our second research objective is to explore the possibility that the provision of employment security affects this relationship. As we argue below, employment security may encourage greater employee and union acceptance of high performance $H R$ practices, thus mediating the observed union-HPWS association. If such a mediating relationship exists, this may help explain conflicting extant results. We examine these research questions in the context of the dynamic economy of the Republic of Ireland.

\section{Unions and HPWSs}

Despite positive evidence for the effectiveness of high performance work systems, studies to date indicate that the adoption of these types of practices is somewhat limited and sporadic (Godard 2004; Roche 1999). As such, identifying factors that inhibit or enhance the uptake of these practices seems both theoretically and practically important. Among the factors that may influence HPWS use, one that has attracted the attention of a number of scholars is the role that unions may play in this process. While some have argued that high performance work systems and unions tend to be incompatible, others have suggested that this is not necessarily the case. Cooke's (1994) study, for example, indicated that employee participation programs contributed more to value added per employee in unionized firms than in non-unionized firms, while gainsharing programs contributed more to performance in non-unionized firms. As noted by Kizilos 
and Reshef (1997), in unionized settings, union leaders will likely influence the extent to which HR innovations are successfully or unsuccessfully implemented:

Management ... plays an important role in supporting an HRM innovation by providing resources, training, support, and information access. In unionized workplaces, however, the role of the union leadership may be equally important. Workers' attitudinal and behavioral reactions to HRM innovation can be influenced by the guidance they received from their local union leaders. (p. 642)

In this section we review the arguments and relevant empirical evidence surrounding the question of unions and HPWSs.

Enhancing effects. A number of scholars, but most especially Thomas Kochan (Kochan 1995; Kochan and Osterman 1994; Rubenstein and Kochan 2001), have argued that high performance work practices are compatible with the interests of unions. In fact, these scholars argue that due to the promise of "mutual gains" for involved parties, the use of high performance work systems "creates opportunities for union renewal, enabling unions to discard their traditional, adversarial role in favour of a new, partnership one. Thus, the high-performance paradigm is best practice not only for employers, but also for workers and, potentially, for their unions" (Godard 2004:349). Drawing on the work of Freeman and Rogers (1999), Kochan argues that union members are interested in having more involvement in the workplace and, increasingly, less interested in adversarial industrial relations, instead favoring more co-operative relationships with management (Roche and Geary 2002).

Some have claimed that unions promote the use of innovative HR practices. One argument, building on the concept of $\mathrm{X}$ inefficiency (Liebenstein 1966), is that unions may engender "shock" and "voice" effects, leading management to adopt more progressive, efficiency-enhancing HR innovations. As noted by Verma (2005),

It is very hard for management, a hierarchical organization, to develop the most efficient process on its own because of its inherent inability to question hierarchy or the dominant paradigm. The implication is that when unions enter the scene they are able to question management. Such questioning sets up a dialectic, otherwise absent from managerial deliberations, which lead to better, more creative and, hence, more productive solutions. (p. 420)

Verma used Rubenstein and Kochan's (2001) case description of Saturn to illustrate how union representatives may be more willing to "tell it like it is," leading to improved management practice. Verma reviewed existing evidence on the association between unionization and use of HR policies and practices, and found positive union effects on training, selection practices, and employee voice mechanisms and negative effects on the use of formal performance appraisal and flexible job arrangements. Thus, in his view, unions may sometimes lead firms to use more progressive HR policies and practices.

Machin and Wood (2005) also provided empirical evidence on the relationship between HR policies and practices and unionization. Their main focus was on whether modern HR policies and practices serve as a "substitute" for unions, thus leading to union decline. Discussed by authors such as Fiorito (2001), the "HRM as substitute" hypothesis suggests that the use of these types of HR policies tends to decrease worker dissatisfaction, a prime cause of unionism. Thus, in this view, greater use of high performance or high commitment HR practices should be associated with reduced union representation. Machin and Wood argued, however, that many of the components of a high performance HR system (for example, training, fair selection processes, and priority given to internal recruitment) are consistent with the interests or demands of unions and may act as a complement to, rather than a substitute for, unionism. These authors presented longitudinal data tracing trends in unionism and HR practice usage (for example, use of flexible pay, use of participatory and communication mechanisms) in Great Britain. Their findings did not reveal a faster uptake of $\mathrm{HR}$ practices in non-union workplaces than in union workplaces or a faster union decline in workplaces or industries displaying a faster adoption of $\mathrm{HR}$ practices. Thus, they found little support for 
the "HRM as substitute" hypothesis. Other evidence has suggested that the association between union representation and indices of high performance HR practices is either positive (Millward 1994; Milner and Richard 1991) or small to nonexistent (Eaton and Voos 1992; Gittleman, Horrigan, and Joyce 1998; Godard 1997; Wood 1996).

Inhibitingeffects. Because innovations often result in replacing or transforming existing organization practices, "the very existence of a potential innovation poses a threat to vested interests" (Kanter 1988:171). Unions may resist any innovation if it is perceived as a threat to their entitlements and influence (Daft and Becker 1978). For example, Ortiz (1999) found that unions in the U.K. subsidiaries of a U.S. multinational corporation resisted the introduction of team-working because it challenged their core interest in the control of work organization. As noted, the "HPWS as union substitute" effect suggests that a system of high performance practices will weaken support for unions because these systems provide individualized voice mechanisms and equitable treatment for workers without the need for collective arrangements (Fisher 1997; Godard 2004; Kizilos and Reshef 1997). Extensive employee involvement may lead workers to assume responsibilities previously reserved for supervisors and managers, leading to an erosion of union solidarity (Kizilos and Reshef 1997). In addition, in labor markets where union-management relations have been historically adversarial (such as the United States and Ireland), the emphasis on cooperation in the high performance work environment may undermine the historical role of unions (Godard 2004). In these contexts, unions have historically attempted to limit managerial discretion and flexibility in terms of staffing, rewards, and so on through the use of detailed work rules. In the HPWS workplace, there is reduced rules-governed decision-making and more autonomy on both sides. More generally, the introduction of high performance HR practices "may disrupt the labor-management relationship by introducing significant changes in the workplace, such as job elimination, job creation, new skill require- ments, new worker responsibilities, and new subordinate-superior relationships" (Kizilos and Reshef 1997:641). Because unions may have both the motivation and the capacity to limit the full implementation of a high performance work system, many argue there is an inherent tension between unions and these systems (Guest 1995).

Critics of "workplace partnership" arrangements between workers and management, such as those characteristic of HPWSs, believe these arrangements to be unsustainable. Streeck (1992) suggested that in the absence of strong institutional constraints, such as those found in the German labor market, the imbalance of power between labor and management will undermine partnership efforts because partnership will only be sought if it serves management's interests. Thus, in weakly regulated labor markets, union interests will not be well served by cooperative, high performance work systems. Similarly, Kelly (1996) sees no particular advantage for unions in partnership arrangements and believes management often uses them as a pretext for resisting or "moderating" unions. ${ }^{2}$

Empirically, a number of studies have suggested that there is an uneasy relationship between unions and high performance work

\footnotetext{
${ }^{2}$ It is important to distinguish between two levels of partnership in the extant literature: (i) social partnership, which focuses on national-level tripartite agreements between unions, management, and government concerning wages and social policy, and (ii) workplace partnership, which is at the enterprise level and focuses on mutuality in employment relations matters between management and employees/unions. Since our study is at the enterprise level, we focus more on the latter form of partnership, although as we discuss below, Ireland's emphasis on social partnership is an important contextual background factor. As described by Guest and Peccei (2001), workplace partnership represents a concerted effort by owners and managers to create an environment where employees have a significant psychological stake in the success of the organization. This is achieved by building high levels of attachment, commitment, and involvement in the enterprise. In addition, a partnership philosophy relies on both employees and management focusing on shared goals and interests without being derailed by perceived differences on specific issues. Partnership represents a philosophy of integration and mutuality, and as such, we believe that a partnership orientation will often be manifested in the use of management practices comprising a high performance work system.
} 
systems. Research suggests that collaboration with employers can generate problems for local unions over time. Wells (1993) examined the implications of high performance practices for unions in five companies. The author found that high performance practices resulted in strains between the union's traditional role and the new, more cooperative arrangement. As a result, these practices seemed to survive only where the union was already weak. Otherwise, the union found it necessary to revert to its traditional adversarial role. The author also concluded that a few of the companies used their experiences with these practices as models for establishing non-union workplaces. Fiorito, Lowman, and Nelson (1987) found that when high performance work practices were in place, the likelihood of a union being established was significantly reduced. Kochan, McKersie, and Chalykoff (1986) found similar results, with this finding magnified when employers reported union avoidance to be a priority. The results of a study by Freeman, Kleiner, and Ostroff (2000) suggest that employee attitudes toward unions may be influenced by the use of high performance systems. They found that $25 \%$ of workers in firms using HPWSs would vote for a union, versus $40 \%$ of workers in firms without such systems.

Evidence also suggests that some firms adopt high performance work systems in part to reduce union influence, although other objectives (for example, cost reduction, improved product quality) tend to be more important (Godard 1998). While Wood (1996) found no general relationship between the use of high commitment management and union presence, his results do suggest that unions negatively affect the rate of diffusion of these practices. Huselid and Rau (1997) found that the degree of workplace union representation had statistically significant negative implications for the adoption of HPWSs. In a study of particular relevance to the present effort, Roche (1999) obtained data from a sample of Irish firms and found that companies with no employee union representation were three-and-a-half times more likely to adopt a bundle of commitmentoriented HR practices than were firms having union representation.
Thus, while some have argued that high performance work systems are compatible with and may even advance the interests of unions, others depict an inherent tension between unions and HPWSs. Although somewhat equivocal, available evidence suggests a neutral to negative association between unionized settings and HPWS adoption.

\section{The Irish Context}

Although Ireland became known as the "Celtic tiger" during the 1990s, experiencing an unprecedented era of rising profits, household income, and job growth, the economy has cooled somewhat in recent years. In terms of labor relations, the Republic of Ireland lacks strong institutional/legislative support for unions (Roche and Geary 2002; Streeck 1992). At the same time, however, Ireland has relatively high levels of union density (Wallace, Gunnigle, and MacMahon 2004). After reaching a record level of $62 \%$ in 1980 , union density in Ireland has fallen in recent years, but remains comparatively high in the European context, standing at about $35 \%$ as of 2005 (Central Statistics Office, Republic of Ireland). Similar to the situation in the United States and other countries, the recent decline in union representation rates in Ireland is principally attributed to macroeconomic factors and changes in employment structure involving employment decline in traditionally highly unionized sectors and employment growth in sectors that have traditionally posed difficulties for union penetration (Roche and Ashmore 2001). Also similar to the United States, Ireland has a "long history of low-trust, adversarial industrial relations" (Roche 1999:655).

An important contextual or background factor that clearly sets Ireland apart from the United States, however, is the "social partnership" movement. Adopted in the late 1980 s as a way to help "cure" a stagnating economy, social partnership in Ireland has involved tripartite agreements between unions, management, and government on wage and social policy issues. Trade unions have played a crucial role in the six centralized agreements that have been forged since 1987 and have been active proponents of 
the social partnership movement (Wallace et al. 2004). These agreements, especially the wage agreements, are thought to have played an important role in the economic transformation of Ireland during the 1990s (Baccaro and Simoni 2007).While the social partnership movement differentiates Ireland from the United States, there are parallels in calls for enterprise-level partnership models in the two countries. Similar to developments in the United States (for example, Kochan 1995; Rubenstein 2001), economic realities and the decline in union density have led some to argue that unions in Ireland should move away from their traditional/historical adversarial mode toward more of a cooperative (that is, "workplace partnership") model to enhance their legitimacy and sustainability (Wallace et al. 2004). Again, as in the United States, it is clear that attempts to move toward workplace partnership are complicated by an adversarial history. D'Art and Turner (2005), for example, question the extent to which partnership has led to true cooperation between employers and unions. Others have described workplace partnership in Irish organizations as "more rhetoric than reality" (Gunnigle 1997). There remains a strong belief in many quarters, however, that some form of workplace partnership is necessary if Irish organizations are to meet the challenges of advancing competitiveness while at the same time providing employees with employment stability and quality of life (O'Donnell and Teague 2000).

The relationship between unions and the adoption of high performance work systems has been incorporated into discussions of workplace partnership in Ireland. Wallace et al. (2004) argued that trade unions play a critical role in influencing the deployment of HPWSs and that HPWSs are most effective when combined with direct and indirect forms of employee involvement. They suggested that such a work system is best facilitated if there is trade union involvement. They, along with others such as Geary (1996; 1999), have argued that union involvement in the implementation of high involvement or high performance work systems is advantageous for a number of reasons, including the legitimization of the change to their members. According to this view, the involvement of unions in the adoption of high performance work systems may help ensure that mutual gains are realized.

\section{A Role for Employment Security?}

Proponents of high performance work systems often argue that employment security is an important part of the implicit contract in the high performance work organization (for example, Pfeffer 1998). As outlined in discussions surrounding other work innovations introduced over the years (for example, gainsharing), employment security is often described as a quid pro quo for employees' committing to managerial policies or practices perceived to contain an element of risk. The "risk" associated with HRM innovations that increase workplace efficiency is the possibility of decreased demand for labor and subsequent employee attrition. A major role of unions is to provide workers with protections against job loss, and, as noted by Levine and Tyson (1990:210), "workers are unlikely to cooperate in increasing efficiency if they fear that by so doing they jeopardize their jobs." This viewpoint dates back to Selig Perlman, who argued that American workers and unions tend to be "job conscious" and will cooperate with management in improving workplace efficiency to the extent that employment stability is enhanced (Perlman 1928:169).

Like their American counterparts, Irish union members tend to be less concerned about political ideology and class interests than with pragmatic bread and butter issues such as job security. As in the United States, in Ireland recent "industrial actions" (strikes) have often been motivated by concerns over redundancies (layoffs). Recent high-profile examples include Irish Ferries, Ltd. (Lavery 2005) and the firm of Guinness, both of which recently faced strikes over announced layoffs of several hundred plant workers (Taylor 2008). In the Irish Ferries case, the protest over the possible dislocation of Irish ferry workers resulted in the largest country-wide strike in over 25 years, with nearly 100,000 people taking to the streets in December 2005. 
One of the more consistent research findings is that use of HPWSs tends to increase work force productivity. The productivity effects associated with HPWSs are partly due to these systems' positive effects on the depth and breadth of firm-specific human capital, which can be characterized as transactionspecific assets (Anderson 1985). Transactionspecific assets are more constrained in their application because they are tailored to the needs of a particular user. For example, machinery dedicated to the production of a manufacturer's unique product design would be a transaction-specific asset to the degree that the machinery has limited or no value to firms other than the current user. Transaction-specific assets can also be human in nature, in the form of special-purpose knowledge or skills (Anderson 1985). As with other types of special-purpose assets, while transaction-specific human assets represent a source of value to a particular firm, they are less valuable to other firms. As such, employees bear some risk under HPWSs to the extent that they invest in firm-specific skills. Rational agents, although they may be attracted by the higher wages that are typically earned in an HPWS environment (Bailey etal. 2001), will be reluctant to assume such risks unless there is some assurance by the firm that it will avoid layoffs engendered by enhanced productivity (Marshall 1992; Kochan and Osterman 1994).

Against the backdrop of global competition and evidence that transformed work systems (for example, use of self-directed work teams, flexible work assignments, and participatory mechanisms) result in gains in productivity and quality, Rubenstein (2001) has argued that unions need to re-orient and restructure themselves toward "value-added unionism," which he defines as labor institutions that work toward increasing firm value and, by extension, value to their membership. He believes that this reorientation is necessary to make unions more appealing to potential union members and better adapted to current economic realities. He cautions, however, that job security is "necessary for effective efforts to increase employee participation" (p. 586) and that the move toward "value-added unionism" is "bounded by the firm and typically based on a commitment to employment security" (p. 593).

In his study of the relationship between unionism and "high commitment management" (HCM), Wood (1996) speculated that the nature of the relationship might be influenced by a number of conditions such as fear of unemployment. Similarly, in their case study of the partnership initiative between Ireland's state-owned Airports Authority, Aer Rianta, and employee unions, Roche and Geary (2002) noted that an important condition underlying this effort was management's assurance of the "representational status and institutional security of the unions." The authors argued that the provision of employment security was an important component of the unions' willingness to cooperate in the partnership arrangement. Like Streeck (1992), Roche and Geary further noted that these assurances are particularly important in countries (Ireland among them) lacking legislative frameworks providing institutional security for unions. Absent meaningful assurances of employment security, unions that cooperate may be marginalized and member support undermined (Marks, Findlay, McKinlay, and Thompson 1998).

With specific reference to Ireland, Roche (1999) indicated that providing employment security will likely play a role in softening union resistance to $H R$ innovations:

To date the innovators in commitment-oriented HRM have mainly been organizations capable of developing and implementing HRM practices without having to concern themselves with the views and potential opposition of trade unions. The recent shift of focus in Irish trade union strategy toward a willingness to accept "soft" HRM practices, provided that union and employment security are underwritten by management, suggests that in future the unionization variable may become less significant for the incidence or diffusion of coherent bundles of HRM practices. (p. 670) ${ }^{3}$

In the next section, we describe our sample and method for investigating two research

\footnotetext{
${ }^{3}$ Soft HRM is somewhat analogous to a "partnership" philosophy. As described by academics such as Storey (1992) and Legge (1995), soft HRM focuses on relationship building, mutuality, and involvement, reflecting the view that employees are valuable resources.
} 
questions. First, does union presence in a firm reduce the likelihood that it will use a set of high performance work practices? Second, does the provision of employment security affect this relationship?

\section{The Study}

Sample. The intended sample was a representative, multi-industry set of Irish-based operations. The sample was drawn from the "The Irish Times Top 1000 Companies" (see http://www.businessworld.ie/) and "Ireland's Top 1000 Companies" (Kompass Ireland Publishers, http://www.kompass. ie/). These represent the "top" firms in terms of size (based on sales revenue/assets). These sources provide a comprehensive, authoritative listing of firms having operations in Ireland. Moreover, they provide the names and addresses of members of the top management group (for example, MD/ CEO, head of finance, head of marketing, and head of HR). There were 1,338 firms in the initial sample.

Procedure. The basic procedure was to solicit survey-based measures of organizational characteristics and HR practices. To achieve this objective, two separate survey instruments focusing on "General Management Practices" and "Human Resource Practices" were sent to the Managing Director (MD) and to the top HR manager, respectively. The GM survey obtained measures on a variety of organizational characteristics. In addition to repeating some of these same measures (to assess measurement reliability), the HR Practice Survey asked respondents to "describe HR practices in your operations in Ireland during 2003-04." After pilot testing, surveys were mailed in mid-year 2004 to the executives identified in the sample firms. This was followed by reminder letters, a second survey follow-up, and, finally, a telephone reminder. We received 204 completed HR surveys and 246 completed GM surveys representing 285 separate companies. For the purposes of this paper, we use the 165 companies for which we have both the HR and GM survey responses. The median firm in the final sample had 323 employees and \pm 75 million in annual sales.

Survey-based studies of "high performance work systems" reviewed by Becker and Huselid (1998) had response rates ranging from $6 \%$ to $28 \%$, and the response rates in studies reviewed by Wall and Wood (2005) averaged approximately $39 \%$. Given that our response rate, $12.3 \%$, is at the lower end of the range found for those previous studies, we checked for possible non-response bias using a "time trend extrapolation test" in which "late" versus "early" respondents were compared along key study variables (first suggested by Oppenheim 1966). The assumption behind this test is that "late" respondents (those whose responses are received after the second round of mailing and follow-up telephone calls) are very similar to non-respondents, inasmuch as theywould have fallen into the non-response category had it not been for the follow-up efforts (Armstrong and Overton 1977). T-tests showed no statistically significant differences between "early" and "late" respondents along any of the key study variables (for example, firm size, company age, union density, HPWS). In addition, we were able to compare responding versus nonresponding firms using limited data available from the 2003 version of the Irish Times Top 1000 set of companies. Specifically, we used these data to compare respondents to nonrespondents on sales revenue and number of employees. Although responding firms had slightly higher values for sales revenue and number of employees, none of these small differences achieved statistical significance (the respective $t$-values for the mean difference tests were .68 and .76 , both $p>.10$ ). While these comparisons do not rule out systematic non-response bias, they do lessen this concern.

\section{Measures}

HRM: high performance work systems. Much recent work in the SHRM literature has focused on firms' use of a system or bundle of high performance HR practices. As such, following the suggestion of Becker and Huselid (1998) and the extant empirical literature (for example, Datta et al. 2005; Roche 1999), we focus on HR practices at the system level. While various approaches to measuring high performance work systems exist in the literature, our measure is explicitly based on the work of Datta et al. (2005), which, in turn, 
draws on Huselid (1995). Consistent with Datta et al., we asked HR survey respondents to describe their firm's relative use of 18 practices for two categories of employees (Table 2 provides more complete information on the individual HR items). Group A employees comprised production, maintenance, service, and clerical employees. Group B employees comprised executives, managers, supervisors, and professional/technical employees. Respondents indicated the proportion of each group covered by each practice. For each firm, these proportions were used in conjunction with the number of employees in each category to compute a weighted average (Cronbach's alpha $=.76)$. Higher scores for a particular practice (that is, closer to $100 \%$ ) indicate more intensive use of that practice. A high score on the high performance work system measure indicates relatively intensive use of a high performance work system; lower scores on this measure indicate less extensive use of a high performance work system. Although we do not have multiple respondents for the HR measure in this study, inter-rater reliability evidence for this 18-item measure $\left(\mathrm{ICC}_{1}=.62\right)$ provided by Datta et al. (2005) suggests that multiple respondents are consistent in their descriptions of their firm's use of HPWSs. ${ }^{4}$

Union membership rates. As in other studies (for example, Guthrie 2001; Huselid 1995), union membership rates for each firm were collected from key organizational informants. These data were collected by asking the rate of union membership for each of the two employee groups via the HR survey (What proportion of your work force is unionized?). We then created a weighted average to reflect the overall proportion of employees in each firm represented by a union. It is worth nothing here that in many European countries

${ }^{4}$ Our HPWS outcome measure is non-continuous and, as such, technically violates an assumption of the analytical technique employed in this paper, OLS regression. However, the HPWS measure has a broad theoretical range ( 0 to 100 , with actual sample values ranging from 19.4 to 80.7 ) and is normally distributed, with 141 of the 142 cases taking on distinct values. These features make OLS modeling an appropriate analytical choice (Labovitz 1967). collective agreements negotiated between unions and employers are legally extended to cover all similar employees in the firm or an entire industry. As such, the collective agreement on wages and conditions of employment covers both the unionized and the non-union employees in a firm or industry. However, this is not the case in Ireland, where only union members are covered by collective agreements. Thus union membership is coterminous with collective bargaining coverage.

Employment security. Employment security was measured using multiple items drawn from the HR and GM survey responses. Three items appeared in both surveys (Our employees can expect to stay with the organization as long as they wish; Our company is committed to a goal of long-term employment security; If this organization were facing economic problems, employee downsizing would be the last option used). The HR and GM surveys also contained items unique to these respective surveys. Thus, the GM and HR surveys each had a total of four items measuring firms' employment security policies. In addition to the above three items, the GM survey respondents were asked to indicate their level of agreement with the statement, Organizations should provide long-term security for all employees. Unique to the HR survey, respondents were asked to estimate the proportion of employees who Have job security: Employment with the firm is almost guaranteed. The question, constructed similar to the other HR practice items, asked the HR respondent to estimate the percentage of each of the two employment groups covered by this practice. Following a z-score transformation to standardize item scales, the internal reliability values (Cronbach's alphas) of the GM and HR employment security scales were computed as .74 and .70 , respectively. Aggregation of these employment security estimates from the two respondents is justified if evidence suggests agreement among each firm's respondents. Glick (1985) argues that $\mathrm{ICC}_{2}$, the group-level intra-class correlation, is the appropriate statistic to justify aggregation. With an $\mathrm{ICC}_{2}$ value of .61, our measure exceeds the threshold established by Glick (1985). James (1982) argued in favor 
of aggregation justification based on $\mathrm{ICC}_{1}$, the individual-level intra-class correlation coefficient. Our ICC $_{1}$ value is .42 , a value that, according to available standards (for example, Bliese 2000; Gerhart et al. 2000), would be considered "large" and supportive of an acceptable degree of agreement across raters. Finally, if we simply compute the internal consistency of the eight security items (four from the GM survey and four from the HR survey), the computed Cronbach's alpha is .76. In sum, both the inter-rater and internal reliability indices support the reliability of this measure.

As a final assessment of this measure, we examined the association between the eightitem employment security scale and firms' downsizing histories. Firms that report higher levels of employment security should, on average, be less likely to downsize (Guthrie and Datta 2008). Consistent with previous work (for example, Cascio et al. 1997; Guthrie and Datta 2008), we used employment-level change data to create dichotomous variables representing firms that reduced their work force $(=1)$ and those that did not $(=0)$. Using year-to-year employment-level changes, the most common cutoff is $5 \%$ (for example, Cascio et al. 1997; Guthrie and Datta 2008). Our survey respondents provided data on employment levels "three years ago" and at the time of survey administration. We used these data to compute employment-level change and found very strong agreement across our two informants. We thus averaged the GM and HR respondents' growth figures $\left(\mathrm{ICC}_{2}=.84\right)$. Following previous work, we used the employment-level change percentages to compute dichotomous measures of downsizing. We used three alternative construct operationalizations, corresponding to decreases in headcount of $5 \%, 10 \%$, and $15 \%$. Our employment security scale correlated with these three dichotomous variables at $r$ $=-.34(\mathrm{p}<.001), \mathrm{r}=-.35(\mathrm{p}<.001)$, and $\mathrm{r}=$ $-.32(\mathrm{p}<.001)$, respectively. This evidence supports the validity of our measure of employment security in that firms reporting higher levels of employment security were, in fact, less likely to downsize.

Control variables. We controlled for a num- ber of factors that could influence the use of HPWSs, unionization rates, or both. Firm size is included as a control because it may be associated with the use of HPWSs as well as union presence. Consistent with previous studies (Guthrie 2001; Huselid 1995), we use the logarithm of the number of employees to operationalize firm size. The GM and HR estimates of number of employees were in close agreement, and we used the average of these two responses as our measure $\left(\mathrm{ICC}_{2}=.97\right)$. We also controlled for the age of each firm. The GM and HR survey responses again proved reliably consistent, and we use the average of these responses (corrected for skewness via a log transformation) in analyses $\left(\mathrm{ICC}_{2}=\right.$ $.95)$. Since firms emphasizing technological intensity and innovation may be more inclined to use HR innovations such as HPWSs (Huselid and Rau 1997), we controlled for firms' $R \mathcal{E}{ }^{2} D$ intensity. The HR and GM survey respondents' estimates of $R \& D$ as a percentage of sales displayed consensus $\left(\mathrm{ICC}_{2}=.70\right)$, and we used the natural log transformation of the average of these responses. Relative to foreign-owned multi-nationals, Irish firms may tend to be more unionized and also less likely to use more progressive HR practices. As such, we controlled for country of ownership (Irish-owned coded as "1"; foreign-owned coded as "0").

Because of potential industry differences in HPWSs and unionization, we also controlled for this factor. Dummy codes representing seven industries were created. These industries, with the percentage of sample firms in each, are as follows: transportation and communications (7\%), financial services $(13 \%)$, chemical products $(4 \%)$, retail/wholesale $(8 \%)$, agriculture, energy, or construction $(20 \%)$, service $(15 \%)$, and manufacturing $(33 \%)$. Along with specifying a primary industry sector, respondents were also asked to estimate the proportion of total sales derived from this industry. The average firm derived $96 \%$ of its sales from the designated primary industry. This lack of diversification supports the designation of a primary industry for sample firms.

Finally, we controlled for two perceptual measures that might affect the adoption of HPWSs or unionization rates: GM re- 
Table 1. Constructs, Operationalizations, and Descriptive Statistics.

\begin{tabular}{|c|c|c|c|}
\hline Construct & Operationalization & Mean & s.d. \\
\hline Firm Age & $l_{n}($ years since founding $)$ & 3.72 & .79 \\
\hline Firm Size & $l_{n}($ number of employees $)$ & 6.05 & 1.31 \\
\hline $\mathrm{R} \& \mathrm{D}$ Intensity & $l_{n}(\mathrm{R} \& \mathrm{D}$ as a percentage of sales revenue $)$ & -1.08 & 5.39 \\
\hline Chemical Products Industry & $\begin{array}{l}1 \text { if firm primarily in chemical/pharmaceutical industry; } \\
0 \text { otherwise }\end{array}$ & .04 & .21 \\
\hline Retail Industry & 1 if firm primarily in retail/wholesale industry; 0 otherwise & .08 & .27 \\
\hline Financial Industry & $\begin{array}{l}1 \text { if firm primarily in finance industry (for example, } \\
\text { banking, insurance); } 0 \text { otherwise }\end{array}$ & .13 & .34 \\
\hline Mfg. Industry & 1 if firm primarily in manufacturing industry; 0 otherwise & .33 & .47 \\
\hline Service Industry & 1 if firm primarily in service industry; 0 otherwise & .15 & .35 \\
\hline Transport./Commun. Industry & $\begin{array}{l}1 \text { if firm primarily in transportation or communications } \\
\text { industry; } 0 \text { otherwise }\end{array}$ & .07 & .25 \\
\hline Agric./Energy/Const. Industry & $\begin{array}{l}1 \text { if firm primarily in agriculture, energy, or construction } \\
\text { industry; } 0 \text { otherwise }\end{array}$ & .20 & .40 \\
\hline Country of Ownership & 1 = Irish-owned; 0 = foreign-owned & .58 & .49 \\
\hline Partnership Philosophy & Composite of five GM survey items & 3.92 & .64 \\
\hline Competitive Environment & Composite of two GM survey items & 2.82 & .89 \\
\hline HPWS & Weighted average of 18 high performance work practices & 46.96 & 15.12 \\
\hline Union \% & $\begin{array}{l}\text { Weighted average of percentage of employees represented } \\
\text { by a labor union }\end{array}$ & 33.63 & 32.03 \\
\hline Employment Security & Composite of eight GM \& HR survey items (z-scores) & .014 & .61 \\
\hline
\end{tabular}

spondents' partnership philosophy and their perception of environmental competitiveness. The relationship between managerial values or orientation and HR practices has been the focus of previous research (de Menezes and Wood 2006; Osterman 1994). Osterman (1994) found strong support for the role of managerial values as a determinant of "flexible work practices." We invoke the work of Guest and Peccei (2001), who provided initial empirical work focused on measuring partnership at work, involving beliefs about principles regarding employee treatment and, in turn, employees' responsibilities to organizations. Applying principal components factor analysis (varimax rotation) to the Guest and Peccei partnership items resulted in five items loading on a factor interpreted as representing a partnership philosophy. GM respondents were asked to "indicate the level of support among your top managers for each principle." The items (principles) are the following: Employees should share in the financial success of the company; Employees should be given a chance to enhance their employability; Employees should be kept informed about all business matters; Feedback should be sought from all employees; The skills and competencies of all employees should be systematically developed. These items were averaged to form a composite scale (Cronbach's alpha $=.76$ ). One of the principal arguments proffered for the use of HPWSs is to meet the demands of competitive environments (Pfeffer 1998). Thus, perceptions of market competitiveness may influence the adoption of high performance work systems (Osterman 1994; Huselid and Rau 1997; Roche 1999). As such, we control for GM respondents' perceptions of the extent to which their markets are (a) Very stressful, exacting, hostile; hard to keep afloat and (b) Very safe, little threat to the survival of my company (reverse-coded; mean of items used in analyses).

\section{Analyses and Results}

Table 1 provides operationalizations and 
Table 2. High Performance Work System Items.

What proportion of your employees....

Are administered one or more employment tests (for example, skills tests, aptitude tests, mental/ cognitive ability tests) prior to hiring?

$28.5 \%$

Are hired on the basis of intensive/extensive recruiting efforts resulting in many qualified applicants?

Hold non-entry level jobs as a result of internal promotions (as opposed to hired from outside of the organisation)?

Hold non-entry level jobs due to promotions based upon merit or performance, as opposed to seniority?

Receive formal performance appraisals or evaluations on a routine basis?

Receive formal performance feedback from more than one source (that is, feedback from several individuals such as supervisors, peers and so on)?

$26.8 \%$

Receive compensation partially contingent on group performance (for example, profit-sharing, gainsharing, team-based)?

Are paid primarily on the basis of a skill or knowledge-based pay system, versus a job-based system? (That is, pay is primarily determined by a person's skill or knowledge level as opposed to the particular job that they hold.)

$26.5 \%$

Have been trained in a variety of jobs or skills (are "cross trained") and/or routinely perform more than one job (are "cross utilised")?

Have received intensive/extensive training in company-specific skills (for example, task or firm-specific training)?

Have received intensive/extensive training in generic skills (for example, problem-solving, communication skills, and so on)?

Are involved in programmes designed to elicit participation and employee input (for example, quality circles, problem-solving or similar groups)?

Are provided with relevant operating performance information (for example, quality, productivity, and so on)?

Are provided with relevant financial performance information?

Are provided with relevant strategic information (for example, strategic mission, goals, tactics, competitor information, and so on)

Are routinely administered attitude surveys to identify and correct employee morale problems?

Are organised in self-directed work teams in performing a major part of their work roles?

${ }^{a}$ These percentages represent weighted averages across the two employee groups.

statistics for the study variables. Table 2 presents descriptive information on the individual high performance HR practices. Bivariate correlations (not presented in tabular form) indicate a number of statistically significant and noteworthy relationships. Younger firms $(r=$ $-.20, \mathrm{p}<.01)$, larger firms $(\mathrm{r}=.11, \mathrm{p}<.10)$, and $R \& D$-intensive firms $(r=.21, p<.01)$ were somewhat more likely to make greater HPWS use, whereas Irish-owned firms $(r=-.45$, $p$ $<.001$ ) were not. Firms whose GM respondents reported more of a partnership philosophy ( $r$ $=.23, \mathrm{p}<.01)$ were more likely to use HPWSs. Finally, as union coverage increased, HPWS use decreased $(r=-.19, p<.01)$. In terms of unionization rates, higher union membership was observed in larger $(\mathrm{r}=.26, \mathrm{p}<.001)$ and older $(r=.36, p<.001)$ firms. Industry differences also existed, with significantly higher union coverage found in firms operating in the manufacturing and chemical products sectors, and lower union representation in the services and financial services sectors. No bivariate association ( $r=.021$, n.s.) is observed between HPWSs and employment security provisions.

The primary relationships of interest are examined using OLS regression and moderated multiple regressions (MMR) (Table 3 ). 
Table 3. OLS Regression Results: Union Representation, Employment Security, and HPWSs. ${ }^{a}$

\begin{tabular}{|c|c|c|c|}
\hline Variable & Model 1 & Model 2 & Model 3 \\
\hline Constant & $\begin{array}{l}52.384 \\
(9.033)\end{array}$ & $\begin{array}{l}44.633 \\
(9.362)\end{array}$ & $\begin{array}{l}46.103 \\
(9.270)\end{array}$ \\
\hline \multicolumn{4}{|l|}{ Step 1: Control Variables } \\
\hline Firm Size & $\begin{array}{l}.053 \\
(.785)\end{array}$ & $\begin{array}{c}.889 \\
(.784)\end{array}$ & $\begin{array}{c}.608 \\
(.786)\end{array}$ \\
\hline Firm Age & $\begin{array}{c}-1.959 \\
(1.326)\end{array}$ & $\begin{array}{c}-.865 \\
(1.368)\end{array}$ & $\begin{array}{c}-.809 \\
(1.351)\end{array}$ \\
\hline Manufacturing Industry & $\begin{array}{l}-9.993 * * * \\
(3.072)\end{array}$ & $\begin{array}{l}-8.432 * * * \\
(3.072)\end{array}$ & $\begin{array}{l}-7.176^{* * *} \\
(3.093)\end{array}$ \\
\hline Retail Industry & $\begin{array}{c}-3.996 \\
(4.269)\end{array}$ & $\begin{array}{c}-4.804 \\
(4.194)\end{array}$ & $\begin{array}{c}-4.059 \\
(4.156)\end{array}$ \\
\hline Agric./Energy/Const. Industry & $\begin{array}{c}-17.670 * * * \\
(3.508)\end{array}$ & $\begin{array}{c}-17.718^{* * *} \\
(3.436)\end{array}$ & $\begin{array}{c}-17.059 * * * \\
(3.407)\end{array}$ \\
\hline Financial Industry & $\begin{array}{l}-2.233 \\
(3.669)\end{array}$ & $\begin{array}{c}-2.814 \\
(3.601)\end{array}$ & $\begin{array}{c}-2.144 \\
(3.570)\end{array}$ \\
\hline Transport./Commun. Industry & $\begin{array}{c}-4.327 \\
(4.661)\end{array}$ & $\begin{array}{c}-3.428 \\
(4.579)\end{array}$ & $\begin{array}{c}-4.021 \\
(4.530)\end{array}$ \\
\hline Chemical Products Industry & $\begin{array}{c}-7.847 \\
(5.309)\end{array}$ & $\begin{array}{c}-6.300 \\
(5.236)\end{array}$ & $\begin{array}{c}-6.123 \\
(5.170)\end{array}$ \\
\hline $\mathrm{R} \% \mathrm{D}$ Intensity & $\begin{array}{l}.276 \\
(.193)\end{array}$ & $\begin{array}{c}.237 \\
(.189)\end{array}$ & $\begin{array}{c}.239 \\
(.187)\end{array}$ \\
\hline Irish-Owned & $\begin{array}{l}-9.753^{* * *} \\
(2.120)\end{array}$ & $\begin{array}{l}-9.707 * * * \\
(2.077)\end{array}$ & $\begin{array}{c}-10.126 * * * \\
(2.060)\end{array}$ \\
\hline Competitive Environment & $\begin{array}{l}-2.463 * * \\
(1.173)\end{array}$ & $\begin{array}{l}-2.549 * * \\
(1.149)\end{array}$ & $\begin{array}{l}-2.708^{* *} \\
(1.137)\end{array}$ \\
\hline Partnership Philosophy & $\begin{array}{l}5.034^{* * * *} \\
(1.626)\end{array}$ & $\begin{array}{l}5.332 * * * \\
(1.597)\end{array}$ & $\begin{array}{l}5.359 * * * \\
(1.576)\end{array}$ \\
\hline Employment Security & $\begin{array}{c}-2.502 \\
(1.793)\end{array}$ & $\begin{array}{c}-2.461 \\
(1.756)\end{array}$ & $\begin{array}{c}-2.301 \\
(1.735)\end{array}$ \\
\hline \multicolumn{4}{|l|}{ Step 2: Independent Variable } \\
\hline Union \% & & $\begin{array}{l}-.089 * * * \\
(.035)\end{array}$ & $\begin{array}{l}-.092 * * * \\
(.035)\end{array}$ \\
\hline$\Delta \mathrm{R}^{2}$ & & $.027 * * *$ & \\
\hline
\end{tabular}

Step 3: Interaction Term

Union\% $\times$ Emp. Security

$\Delta \mathrm{R}^{2}$

Unadjusted $\mathrm{R}^{2}$

Adjusted $\mathrm{R}^{2}$

Model F

.445

.388

$7.889 * * *$

.472

.413

.489

.428

N

142

8.094***

$8.036 * * *$

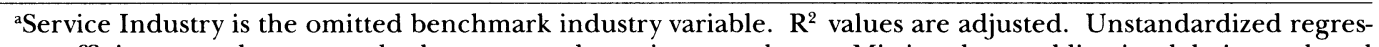
sion coefficients are shown; standard errors are shown in parentheses. Missing data and listwise deletion reduced the sample to $\mathrm{n}=142$ for OLS analyses.

*Statistically significant at the .10 level; **at the .05 level; ***at the .01 level (all tests are two-tailed).

Model 1 is restricted, and model 2 is the full model, including the "union effect." First, we find, consistent with the bivariate results, that HPWS use varied across industry sec- tor. Companies designated as competing in agriculture, energy, and construction or in manufacturing tended to make less HPWS use $(p<.001)$ than did the service industry 
(omitted benchmark industry variable). Other factors predicting greater HPWS use include top management exhibiting more of a partnership philosophy $(\beta=.22 ; \mathrm{p}<.001)$ and perceiving the environment as being more competitive and risky $(\beta=.16 ; \mathrm{p}<.05)$. Irish-owned firms were much less likely to use a high performance HR system $(\beta=-.33$; $\mathrm{p}<$ $.001)$. Finally, consistent with expectations, above and beyond the influence of all other factors in the model, increases in employee union membership lessened HPWS use $(\beta=$ $-.19 ; \mathrm{p}<.01)$, accounting for an additional $2.7 \%$ of variance $(\Delta F=6.42 ; \mathrm{p}<.01)$. Overall, model 2 accounts for $41.3 \%$ of the variance in HPWS use $(F=8.09 ; \mathrm{p}<.001)$.

The above results support the first study hypothesis. The second hypothesis was tested using moderated multiple regression (MMR). As indicated in Table 3 (model 3), the inclusion of the interaction term (the product of union membership rates and the employment security scale) accounts for a statistically significant amount of additional variance $(\Delta F=$ $4.29 ; \mathrm{p}<.05)$. Figure 1 illustrates this interaction and aids in its interpretation. This figure contains two panels illustrating the nature of the slopes for different values of employment security and union density. Panel (a) uses $\pm 1.0 \mathrm{SD}$ for both union representation and employment security, while Panel (b) uses \pm 1.5 SDs. As indicated by these figures, when employment security provisions were "low," there was a relatively sharp decrease in the use of HPWSs as we move from low to high union representation. This decline is more precipitous in Panel (b). In Panel (a), there is a modest negative slope in the "High Security" group, indicating that HPWS use decreased only slightly as employee union membership increased. In Panel (b), however, the slope is positive, indicating slightly greater use of HPWSs as union membership increased. We calculated the point of inflection-the value for our employment security measure where, for the average firm (in terms of union density and the other predictors), the effect of union membership on HPWS utilization drops to zero. The precise value for employment security where this takes place is .793, which is 1.26 standard deviations above the sample mean, or at about the
Figure 1. Union Representation and Use of HPWS as Moderated by Employment Security.

(a) Using +1.0 SD

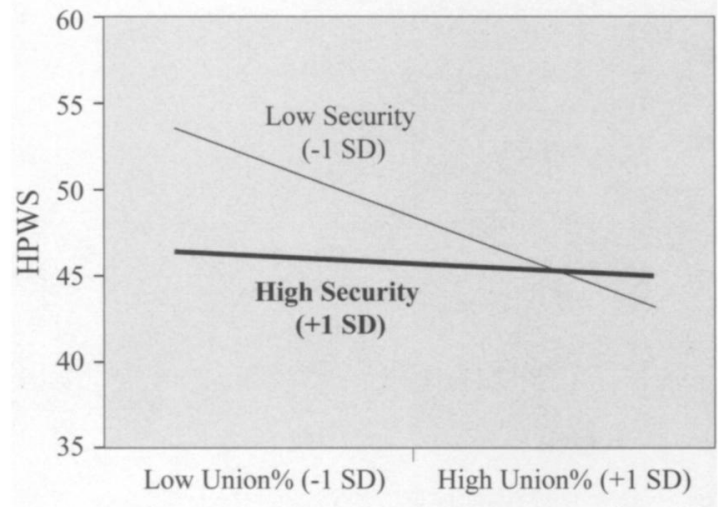

(b) Using +1.5SD

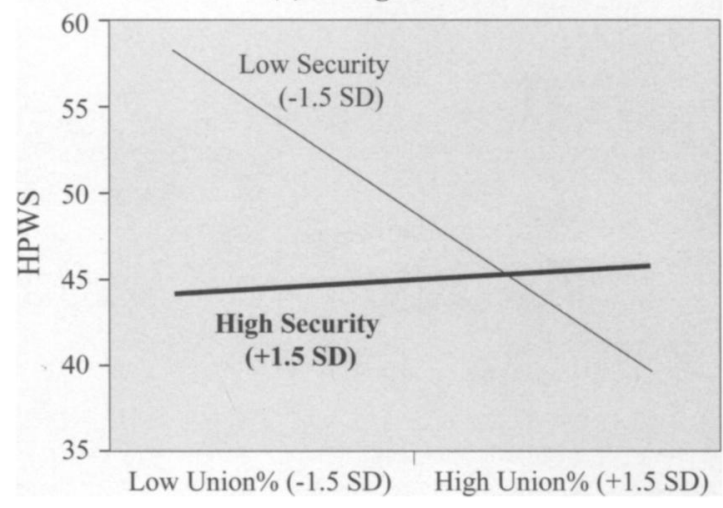

$90^{\text {th }}$ percentile within our sample. Above this value for employment security, increases in union representation were associated with modest increases in HPWS use. In other words, when employment security provisions were very strong (in the top $10 \%$ of our sample), union representation correlated modestly and positively with greater use of high performance work systems.

In sum, the MMR results and the additional analyses provide support for the conclusion that the provision of employment security tempers the negative effect of union presence on the relative use of high performance work systems. When employment security strengthens, the negative impact of the presence of unions on these HR practices is attenuated. 


\section{Discussion and Conclusions}

As our literature review in this paper showed, some authors believe unions may enhance the adoption of HPWSs and others argue the reverse. Given the setting of our study, a country with relatively unfettered labor markets in tandem with a history of adversarial labor relations, we were not surprised to observe a negative impact of unions on the relative use of HPWSs. This result holds after we control for the influence of a host of other factors, including industry, national ownership, environment, and managerial values.

A primary contribution of this study is our exploration of the mediating influence of employment security provisions on the union-HPWS relationship. Scholars have suggested that the future of unions will be enhanced if they actively partner with firms and managers to promote and implement cooperative, value-adding workplace practices (Kochan and Osterman 1994; Rubenstein 2001). Further, a number of authors have suggested that if unions and employees feel more secure in their jobs, they will be more receptive to working with management in implementing transformed work systems designed to improve labor productivity (Levine and Tyson 2000; Roche 1999; Roche and Geary 2002; Rubenstein 2001; Wood 1996). Previous work, however, has not explicitly tested these arguments with respect to the use of high performance work systems; our results support the validity of these arguments. We find that the negative association between unions and use of HPWSs was strongest when employment security was low, and that the magnitude of the effect fell sharply as employment security increased. Our expectation was that stronger employment security provisions would soften the constraints placed on HPWS adoption by the presence of unions. In fact, we find some evidence that the relationship between union membership and use of HPWSs became positive in the context of very strong employment security provisions. While we did not explicitly predict this latter result, it is consistent with discussions found in the literature suggesting that unions can either constrain or facilitate the implementa- tion of management innovations, depending on the quality of labor-management relations (for example, Kizilos and Reshef 1997). If union leadership advises members that supporting HR innovations will lead to layoffs or more stressful working conditions, then resistance to their implementation will likely follow. If, on the other hand, union leaders endorse and support workplace changes, implementation may be enhanced.

Ireland's economic revival prior to the current economic crisis was largely dependent on the attraction of multinational firms (including many from the United States) wishing to use Ireland as a platform to serve the entire European community. This led to an increase in foreign direct investment and the arrival of large numbers of immigrant workers. The global financial crisis has affected both of these factors. In the United States, the Obama administration is encouraging American multinationals to repatriate overseas foreign operations back to the United States, while the general slowdown in economic activity in Ireland has led to many foreign workers returning to their home countries. Job insecurity in Ireland is now at an all-time high. As illustrated by the Irish Ferries case described earlier, the availability of a labor pool comprised of workers often willing to work at lower wages has exacerbated the sense of employment insecurity, especially in (higher-wage) unionized sectors. This has magnified the importance of this issue in Ireland and, we suspect, in many other countries. Concerns harbored by unions about the impact of innovative management practices on their role and future will be particularly salient in environments where employment instability is already an issue. Management, on the other hand, has now the opportunity afforded by the recession to pioneer the introduction of labor efficiency practices.

The findings presented here should be interpreted in the context of a number of study limitations. First, our results are based on a limited sample of firms from the Republic of Ireland. Each country is unique in terms of labor market regulations, industrial relations climate and history, and so on, which may limit generalizability or transportability of 
results. Ireland's adversarial labor relations environment may contribute to the findings reported here. Results in countries with more cooperative industrial relations systems may differ. On the other hand, we would expect our results to generalize to countries with a similar history, such as the United States. In addition, our results may not pertain to the entire Irish economy, since our sample of firms was drawn from a list of some of the larger employers in the Republic. Second, in contrast with, for example, Machin and Wood's (2005) results, ours are derived from a cross-sectional design. Although we imply that the negative coefficient in our models indicates that unions impede the adoption of HPWSs (consistent with the "inhibition" effect), we cannot rule out the interpretation that the presence of HPWSs decreases the potential for the establishment and growth of unionism (consistent with the "substitution" effect). It is important to note, however, that union representation in most sample firms will have pre-dated the more recent interest in innovative HR systems. Third, we suggest that our results indicate union resistance to HPWS adoption and, further, that this resistance lessens in the context of greater assurances of employment security. While our results are consistent with this interpretation, we do not explicitly test union and employee attitudes and how they were influenced by employment security. Fourth, the unionHPWS relationship is likely complex and mediated by a number of factors, including macro-economic conditions and the strength of the labor market (Wood 1996). This suggests that our study's focus on employment security as a moderator is somewhat limited. Future studies might fruitfully examine the effects of other variables-unemployment rates, for example-on the relationship between unionism and HPWSs. Finally, whenever survey response rates are less than $100 \%$, there is the possibility of non-response bias. While we report a test of non-response bias, we cannot be certain that respondents and non-respondents did not differ on unmeasured variables that also correlated with our independent and dependent variables.

As noted, the adoption of high performance work practices is not without its critics.
Some (Wall and Wood 2005) question the true impact of HPWSs on firm performance, while others (Godard 2004; Harley 2001) remain unconvinced that workers typically benefit under these systems. With respect to unionized settings, Kelly (1998) has argued that union militancy will be required to force managers to share the gains of increased productivity with employees. Similarly, in their study of two steelworks, Bacon and Blyton (2007) reported that employee gains were secured only where union negotiators pursued conflict tactics during bargaining.

In contrast, others accept the value of HPWSs and argue that high performance work systems offer the potential of "mutual gains" for both employees and management (Kochan and Osterman 1994; Levine 1995; Appelbaum et al. 2000; Rubenstein 2001). From this perspective, such systems have the potential to benefit both organizations (for example, by increasing productivity and innovation as more employees work both "smart and hard") and employees (by increasing pay, bringing more interesting work, and so on). As such, the National Centre for Partnership and Performance, a government agency under the aegis of Ireland's Department of the Taoiseach (that is, the Prime Minister), has been encouraging cooperation between employers and unions in order to facilitate the introduction of innovative management practices, including high performance work practices. Kochan and Osterman (1994), however, believe this can be achieved only if a climate of trust prevails. Provisions of employment security would seem to be an important aspect of "trust"-in this case trust on the part of employees that they will remain gainfully employed. Jobinsecurity would limit the likelihood that unions will cooperate in pursuing mutual gains-especially since case history suggests that if high performance work practices are implemented in the context of job insecurity, unions and employees may experience less favorable outcomes (Bacon and Blyton 2006).

It is axiomatic that, for many people, change is hard and therefore often resisted. In the workplace, resistance to organizational change is likely to be magnified if (a) employees are uncertain as to the implication 
of changes for future job security and (b) employees have the strength of a union behind them. Mounting evidence indicates that organizational effectiveness can be enhanced through the adoption of high performance work systems. Our research suggests, however, that successful implementation of such systems in unionized settings may depend on providing employees with a strong sense of employment security.

\section{REFERENCES}

$\rightarrow$ Anderson, Erin. 1985. "The Salesperson as outside Agent or Employee: A Transaction Cost Analysis." Marketing Science, Vol. 4, No. 3, pp. 234-54.

Appelbaum, Eileen, Thomas Bailey, Peter Berg, and Anne Kalleberg. 2000. Manufacturing Advantage: Why High-Performance Work Systems Pay Off. Ithaca, N.Y., and London: ILR Press (an imprint of Cornell University Press).

Armstrong, Scott J., and Terry S. Overton. 1977. "Estimating Nonresponse Bias in Mail Surveys." Journal of Marketing Research, Vol. 14, pp. 396-402.

Arthur, Jeffrey B. 1994. "Effects of Human Resource Systems on Manufacturing Performance and Turnover." Academy of Management Journal, Vol. 37, No. 3, pp. 670-88.

Baccaro, Lucio, and Marco Simoni. 2007. "Centralized Wage Bargaining and the 'Celtic Tiger' Phenomenon." Industrial Relations, Vol. 46, No. 3, pp. 426-55.

Bacon, Nicolas, and Paul Blyton. 2006. "Union Cooperation in a Context of Job Insecurity: Negotiated Outcomes from Team Working." British Journal of Industrial Relations, Vol. 44, No. 2, pp. 215-37.

2007. "Conflict for Mutual Gains?" Journal of Management Studies, Vol. 44, No. 5, pp. 814-34.

Bailey, Thomas. 1993. Discretionary Effort and the Organization of Work: Employee Participation and Work Reform since Hawthorne. New York: Institute on Education and the Economy, Teachers College, Columbia University.

$\rightarrow$ Bailey, Thomas, Peter Berg, and Carola Sandy. 2001. "The Effect Of High-Performance Work Practices on Employee Earnings in the Steel, Apparel, and Medical Electronics and Imaging Industries." Industrial and Labor Relations Review, Vol. 54, No. 2, pp. 525-43.

$\rightarrow$ Batt, Rosemary. 2002. "Managing Customer Service: Human Resource Practices, Quit Rates, and Sales Growth." Academy of Management Journal, Vol. 45, No. 3, pp. 587-97.

Becker, Brian E., and Mark A. Huselid. 1998. "High Performance Work Systems and Firm Performance: A Synthesis of Research and Managerial Implications." In Kendrith M. Rowland and Gerald R. Ferris, eds., Research in Personnel and Human Resource Management. Greenwich, Conn.: JAI Press.

Bliese, Paul. 2000. "Within-Group Agreement, NonIndependence, and Reliability: Implications for Data Aggregation and Analysis." In Katherine J. Klein and Steve W. J. Kozlowski, eds., Multilevel Theory, Research, and Methods in Organizations, pp. 349-81. San Francisco: Jossey Bass.

Bryson, Alex, John Forth, and Simon Kirby. 2005.
"High Involvement Management Practices, Trade Union Representation and Workplace Performance in Britain." Scottish Journal of Political Economy, Vol. 52, No. 3, pp. 451-91.

Cappelli, Peter, and David Neumark. 2001. "Do 'HighPerformance' Work Practices Improve EstablishmentLevel Outcomes?" Industrial and Labor Relations Review, Vol. 54, No. 4, pp. 737-75.

Cascio, Wayne F., Clifford E. Young, and James R. Morris. 1997. "Financial Consequences of EmploymentChange Decisions in Major U.S. Corporations." Academy of Management Journal, Vol. 40, No. 5, pp. 1175-89.

Combs, James, Yongmei Liu, Angela Hall, and David Ketchen. 2006. "How Much Do High-performance Work Practices Matter? A Meta-Analysis of Their Effects on Organizational Performance." Personnel Psychology, Vol. 59, No. 3, pp. 501-28.

Cooke, William N. 1994. "Employee Participation Programs, Group-Based Incentives, and Company Performance: A Union-Nonunion Comparison.” Industrial and Labor Relations Review, Vol. 47, No. 4, pp. 594-609.

Daft, Richard L., and Selwyn W. Becker. 1978. Innovation in Organizations. New York: Elsevier North Holland.

D'Art, Daryl, and Thomas Turner. 2005. "Union Recognition and Partnership at Work: A New Legitimacy for Irish Trade Unions?” Industrial Relations Journal, Vol. 36, No. 2, pp. 121-39.

$\rightarrow$ Datta, Deepak K., James P. Guthrie, and Patrick M. Wright. 2005. "HRM and Labor Productivity: Does Industry Matter?" Academy of Management Journal, Vol. 48, No. 1, pp. 135-45.

De Menezes, Lilian M., and Stephen J. Wood. 2006. "The Reality of Flexible Work Systems in Britain." International Journal of Human Resource Management, Vol. 17, No. 1, pp. 106-38.

$\rightarrow$ Delaney, John T., and Mark A. Huselid. 1996. "The Impact of Human Resource Management Practices on Perceptions of Organizational Performance." Academy of Management Journal, Vol. 39, No. 4, pp. 949-69.

Delery, John E., and Harold D. Doty. 1996. "Modes of Theorizing in Strategic Human Resource Management: Tests of Universalistic, Contingency, and Configurational Performance Predictions." Academy of Management Journal, Vol. 39, No. 4, pp. 802-35.

Eaton, Addrienne, and Paula Voos. 1992. "Unions and Contemporary Innovations in Work Organization, Compensation, and Employee Participation." In Lawrence Mishel and Paula B. Voos, eds., Unions and Economic Competitiveness. Armonk, N.Y.: M.E. Sharpe. Fiorito, Jack. 2001. "Human Resource Management 
Practices and Worker Desires for Union Representation.” Journal of Labor Research, Vol. 22, No. 2, pp. 335-54.

Fiorito, Jack, Christopher Lowman, and Forrest Nelson. 1987. "The Impact of Human Resource Policies on Union Organizing." Industrial Relations, Vol. 26, No. 1, pp. 113-26.

Fisher, John. 1997. "The Challenge of Change: The Positive Agenda of the TGWU." International Journal of Human Resource Management, Vol. 8, No. 6, pp.797-806.

Freeman, Richard, Morris Kleiner, and Cheryl Ostroff. 2000. "The Anatomy of Employee Involvement and Its Effects on Firms and Workers." Unpublished paper, National Bureau of Economic Research, Cambridge, Mass.

Freeman, Richard B., and Joel Rogers. 1999. What Workers Want. Ithaca, N.Y.: ILR Press (an imprint of Cornell University Press).

Geary, John F. 1996. "Working at Restructuring Work in Europe: The Case of Team Working." Irish Business and Administrative Research, Vol. 17, pp. 44-57.

1999. "The New Workplace: Change at Work

in Ireland." International Journal of Human Resource Management, Vol. 10, No. 5, pp. 870-90.

Gerhart, Barry. 1999. "Human Resource Management and Firm Performance: Measurement Issues and Their Effect on Causal and Policy Inferences." In Patrick Wright, Lee Dyer, John Boudreau, and George Milkovich, eds., Research in Personnel and Human Resources Management, Suppl. 4, pp. 31-51. Greenwich, Conn.: JAI Press.

Gerhart, Barry, Patrick M. Wright, Gary C. McMahan, and Scott A. Snell. 2000. "Measurement Error in Research on Human Resources and Firm Performance: How Much Error Is There and How Does It Influence Effect Size Estimates?” Personnel Psychology, Vol. 53, No. 4, pp. 803-34.

Gittleman, Maury, Michael Horrigan, and Mary Joyce. 1998. "Flexible' Workplace Practices: Evidence from a Nationally Representative Survey." Industrial and Labor Relations Review, Vol. 52, No. 1, pp. 99-115.

Glick, William H. 1985. "Conceptualizing and Measuring Organizational and Psychological Climate: Pitfalls in Multilevel Research.” Academy of Management Review, Vol. 10, No. 3, pp. 601-16.

Godard, John. 1997. "Whither Strategic Choice: Do Managerial IR Ideologies Matter?" Industrial Relations, Vol. 36, No. 2, pp. 206-28.

1998. "Workplace Reforms, Managerial Objectives, and Managerial Outcomes." International Journal of Human Resource Management, Vol. 9, No. 1, pp. 18-40. 2004. "A Critical Assessment of the High-Performance Paradigm." British Journal of Industrial Relations, Vol. 42, No. 2, pp. 349-78.

Guest, David. 1995. "Human Resource Management, Trade Unions, and Industrial Relations." In John Storey, ed., Human Resource Management: A Critical Text. London: Routledge.

Guest, David, Jonathan Michie, Neil Conway, and Maura Sheehan. 2003. "Human Resource Management and Corporate Performance in the UK." British Journal of Industrial Relations, Vol. 41, No. 2, pp. 291-314.

Guest, David, and Riccardo Peccei. 2001. "Partnership at Work: Mutuality and the Balance of Advantage."
British Journal of Industrial Relations, Vol. 39, No. 2, pp. 207-36.

Gunnigle, Patrick. 1997. "More Rhetoric Than Reality: Enterprise-Level Industrial Relations Partnership in Ireland." Economic and Social Review, Vol. 28, No. 4, pp. 179-200.

$\rightarrow$ Guthrie, James P. 2001. "High Involvement Work Practices, Turnover, and Productivity: Evidence from New Zealand." Academy of Management Journal, Vol. 44, No. 1, pp. 180-90.

$\rightarrow$ Guthrie, James P., and Deepak K. Datta. 2008. "Dumb and Dumber: The Impact of Downsizing on Firm Performance as Moderated by Industry Conditions." Organization Science, Vol. 19, No. 1, pp. 108-23.

Guthrie, James P., Patrick C. Flood, Wenchuan Liu, and Sarah MacCurtain. 2009. "High Performance Work Systems in Ireland: Human Resource and Organizational Outcomes." International Journal of Human Resource Management, Vol. 20, No. 2, pp. 112-25.

Harley, Bill. 2001. "Team Membership and the Experience of Work in Britain: An Analysis of WERS98 Data." Work, Employment and Society, Vol. 15, No. 4, pp. 721-42.

Horgan, Justine, and Peter Muhlau. 2005. "Human Resource Management and Performance: A Comparative Study of Ireland and the Netherlands." Management Review, Vol. 16, pp. 242-58.

Huselid, Mark A. 1995. "The Impact of Human Resource Management Practices on Turnover, Productivity, and Corporate Financial Performance." Academy of Management Journal, Vol. 38, No. 3, pp. 635-72.

Huselid, Mark A., and Barbara L. Rau. 1997. "The Determinants of High-Performance Work Systems: Cross Sectional and Longitudinal Analysis." Proceedings of the 1997 Academy of Management Annual Meetings.

James, Larry R. 1982. "Aggregation Bias in Estimates of Perceptual Agreement." Journal of Applied Psychology, Vol. 67, No. 2, pp. 219-29.

Kanter, Rosabeth M. 1988. "When a Thousand Flowers Bloom: Structural, Collective, and Social Conditions for Innovation in Organization." In Barry Staw and Larry Cummings, eds., Research in Organizational Behavior, Vol. 10, pp. 169-211. Greenwich, Conn: JAI Press.

Kelly, John. 1996. "Union Militancy and Social Partnership.” In Peter Ackers, Chris Smith, and Paul Smith, eds., The New Workplace and Trade Unionism. London: Routledge.

1998. Rethinking Industrial Relations: Mobilization, Collectivism and Long Waves. London: Routledge.

Kizilos, Mark, and Yonatan Reshef. 1997. "The Effect of Workplace Unionization on Worker Responses to HRM Innovation." Journal of Labor Research, Vol. 18, No. 4, pp. 641-56.

Koch, Marianne J., and Ruth G. McGrath. 1996. "Improving Labor Productivity: Human Resource Management Policies Do Matter.” Strategic Management Journal, Vol. 17, No. 5, pp. 335-54.

Kochan, Thomas. 1995. "Using the Dunlop Report to Achieve Mutual Gains." Industrial Relations, Vol. 34, No. 3, pp. 350-66.

$\rightarrow$ Kochan, Thomas, Robert McKersie, and John Chalykoff. 1986. "The Effects of Corporate Strategy and Workplace Innovation on Union Representation." Industrial and Labor Relations Review, Vol. 39, No. 4, pp. 487-501. 
Kochan, Thomas, and Paul Osterman. 1994. The Mutual Gains Enterprise. Boston: Harvard Business School Press.

Labovitiz, Sanford. 1967. "Some Observations on Measurement and Statistics." Social Forces, Vol. 46, No. 2, pp. 151-60.

Lavery, Brian. 2005. "Ferry Dispute Tests Ireland's Tolerance for Globalization." New York Times, December 27.

Legge, Karen. 1995. Human Resource Management: Rhetorics and Realities. Basingstoke: Macmillan.

Levine, David I. 1995. Reinventing the Workplace: How Business andEmployees Can Both Win. Washington, D.C.: Brookings Institution Press.

Levine, David, and Laura Tyson. 1990. "Participation, Productivity, and the Firm's Environment." In Alan S. Blinder, ed., Paying for Productivity. Washington, D.C.: Brookings Institution Press.

Liebenstein, Harvey. 1966. "Allocative Efficiency vs. X-Efficiency.” American Economic Review, Vol. 56, No. 3, pp. 392-415.

MacDuffie, John P. 1995. "Human Resource Bundles and Manufacturing Performance: Organizational Logic and Flexible Production Systems in the World Auto Industry." Industrial and Labor Relations Review, Vol. 48, No. 2, pp. 197-221.

$\rightarrow$ Machin, Stephen, and Stephen Wood. 2005. "Human Resource Management as a Substitute for Trade Unions in British Workplaces." Industrial and Labor Relations Review, Vol. 58, No. 2, pp. 201-18.

Marks, Abigail, Patricia Findlay, Alan McKinlay, and Paul Thompson. 1998. "The Politics of Partnership? Innovation in Employment Relations in the Scottish Spirits Industry." British Journal of Industrial Relations, Vol. 36, No. 2, pp. 209-26.

Marshall, Ray. 1992. "Work Organization, Unions, and Economic Performance." In Lawrence Mishel and Paula Voos, eds., Unions and Economic Competitiveness, pp. 247-86. Armonk, N.Y.: M.E. Sharpe.

Millward, Neil. 1994. The New Industrial Relations? London: Policy Studies Institute.

Milner, Simon, and Edward Richard. 1991. "Determinants of Union Recognition and Employee Involvement: Evidence from the London Docklands." British Journal of IndustrialRelations, Vol. 29, No. 3, pp. 377-90.

O'Donnell, Rory, and Paul Teague. 2000. Partnership at Work in Ireland: An Evaluation of Progress under Partnership 2000. Dublin: Department of An Taoiseach.

Oppenheim, Abraham N. 1966. Questionnaire Design and Attitude Measurement. New York: Basic Books.

Ortiz, Luis. 1999. "Unions' Response to Teamwork: Differences at National and Workplace Level." European Journal of Industrial Relations, Vol. 5, No. 1, pp. 49-69.

Osterman, Paul. 1994. "How Common Is Workplace Transformation and Who Adopts It?" Industrial and Labor Relations Review, Vol. 47, No. 2, pp. 173-88.

Perlman, Selig. 1928. A Theory of the Labor Movement. New York: MacMillan.

Pfeffer, Jeffrey. 1994. Competitive Advantage through People: Unleashing the Power of the Work Force. Boston: Harvard Business School Press. 1998. The HumanEquation: Building Profits by Putting People First. Boston: Harvard Business School Press.
Pil, Frits K., and John P. MacDuffie. 1996. "The Adoption of High Involvement Work Practices." Industrial Relations, Vol. 35, No. 3, pp. 423-55.

Roche, William K. 1999. "In Search of CommitmentOriented Human Resource Management Practices and the Conditions That Sustain Them." Journal of Management Studies, Vol. 36, No. 5, pp. 653-78.

Roche, William K., and Jacqueline Ashmore. 2001. "Irish Unions in the 1990s: Testing the Limits of Social Partnership." In Gerry Griffin, ed., Changing Patterns of Trade Unionism: A Comparison of English Speaking Countries. London: Mansell.

Roche, William K., and John F. Geary. 2002. "Advocates, Critics, and Union Involvement in Workplace Partnership: Irish Airport.” British Journal of Industrial Relations, Vol. 40, No. 4, pp. 659-88.

Rubenstein, Saul. 2001. "Unions as Value-Adding Networks: Possibilities for the Future of U.S. Unionism." Journal of Labor Research, Vol. 22, No. 3, pp. 581-98.

Rubinstein, Saul, and Thomas Kochan. 2001. Learning from Saturn. Ithaca, N.Y.: ILR Press (an imprint of Cornell University Press).

Storey, John. 1992. Developments in Human Resource Management. Oxford: Basil Blackwell.

$\rightarrow$ Streeck, Wolfgang. 1992. "National Diversity, Regime Competition, and Institutional Deadlock: Problems in Forming a European Industrial Relations System." Journal of Public Policy, Vol. 12, No. 4, pp. 301-30.

Subramony, Mahesh. Forthcoming. "Meta-Analytic Investigation of the Relationship between Human Resource Management Bundles and Firm Performance." Human Resource Management.

Taylor, Charlie. 2008. "Strike Threat 'Won't Hit Guinness Supply.'” Irish Times, April 21.

Turner, Lowell. 1991. Democracy at Work: Changing World Markets and the Future of Labor Unions. Ithaca, N.Y.: Cornell University Press.

Verma, Anil. 2005. "What Do Unions Do to the Workplace? Union Effects on Management and HRM Policies." Journal of Labor Research, Vol. 26, No. 3, pp. 415-49.

Wall, Toby D., and Stephen Wood. 2005. "The Romance of Human Resource Management and Business Performance and the Case for Big Science." Human Relations, Vol. 58, No. 4, pp. 1-34.

Wallace, Joe, Patrick Gunnigle, and Gerard MacMahon. 2004. Industrial Relations in Ireland, 3rd ed. Dublin: Gill \& Macmillan.

Wells, Don. 1993. "Are Strong Unions Compatible with the New Model of Human Resource Management?" Relations Industrielles, Vol. 48, No. 1, pp. 56-85.

Wood, Stephen. 1996. "High Commitment Management and Unionization in the UK." International Journal of Human Resource Management, Vol. 7, No. 1, pp. 41-58. Wood, Stephen, and Lillian de Menezes. 1998. "High Commitment Management in the U.K.: Evidence from the Workplace Industrial Relations Survey, and Employers' Manpower and Skills Practices Survey." Human Relations, Vol. 51, No. 4, pp. 485-515.

Youndt, Mark A., Scott A. Snell, James W. Dean, and David P. Lepak. 1996. "Human Resource Management, Manufacturing Strategy, and Firm Performance." Academy of Management Journal, Vol. 39, No. 4, pp. 836-65. 